\title{
Effects of Local Administrations in Maritime Transportation and Coastal Areas: TRNC Case
}

\author{
Ali ÖNCÜํㅜ, Gülsüm BEKTAŞ², Serdar KUM ${ }^{3}$ \\ ${ }^{1}$ İnönü Municipality, TRNC; University of Kyrenia, Faculty of Maritime Studies, TRNC, alioncu1988@hotmail.com \\ ${ }^{2}$ Girne American University, Marine School, TRNC, gulsumbektas@hotmail.com \\ ${ }^{3}$ İstanbul Technical University, Maritime Faculty, Turkey, kumse@itu.edu.tr
}

\begin{abstract}
Municipalities are the institutions which can identify the regional problems better, as they are the closest governmental unit to the public. Ensuring the participation of public in the administration, improving life quality within borders of the municipality, regional public wealth, peace and welfare, meeting the local requirements in a modernized attitude are among the main duties of them. Activity and service areas of local administrations have been increased progressively during the recent years. Since the environmental problems have no limit in their nature, all communities are affected by the increasing regional issues which can be felt globally. Considering the environmental problems only in the surrounding of TRNC and trying to solve those by coastal management systems would not be possible. The environmental problems should be taken into account by the all stakeholders, having integrated coastal management in mind. The priority should be given to protect the environment and prevent pollution by information sharing with interested parties. In this study; local administration approaches on marine environment and marine activities are investigated, and the authority, responsibility and what the local administrations can act on these issues are searched and finally aimed to provide some recommendations for the existing situation in the TRNC.
\end{abstract}

Keywords: TRNC, Local Administrations, Environment Policies, Integrated Coast Management, Maritime Transportation.

\section{Yerel Yönetimlerin Deniz Ulaştırması ve Kıyı Alanlarındaki Etkileri: KKTC Örneği}

$\ddot{O} \mathbf{z}$

Belediyeler halka yakın birimler olmasından ve bölgesel sorunları en iyi bilmelerinden dolayı, halkın katılımını sağlayabilmesi, belediye sınırları içinde halkın yașam kalitesinin gelișmesi, belde halkının refahı, mutluluğu ve esenliği konusunda ortak yerel gereksinimlerin çağdaş bir anlayış ve tutum ile ele alınması gibi yerel yönetim görevleri vardır. Yerel yönetimlerin faaliyet ve hizmet alanları son yıllarda gittikçe daha da artış göstermektedir. Çevre sorunlarının sınır tanımayan özelliği nedeniyle bölgesel sorunların birleșerek küresel boyutta çoğalarak hissetmemizi sağllyor. Çevre sorunlarını sadece KKTC etrafinda düşünmek kıyı yönetim sistemiyle sorunları çözmek mümkün olamayacaktır. Bunun bütünleșik klyı yöntemiyle, tüm paydaşlarla beraber düşünülmeli ve bilgi paylaşımı ile çevre koruması ve çevre kirliliğine öncelik verilmelidir. Bu çalışmada; yerel yönetimlerin çevre ve denizsel faaliyetler konusunda yaklaşımları incelenmiş, yerel yönetimlerin yetki, sorumlulukları ve yapabilecekleri konusunda araştırma yapılarak KKTC'deki mevcut durumlar için öneriler sunulmaktadır. 


\section{Introduction}

Cyprus Island is the third largest island in the Mediterranean Sea, following Sicily and Sardinia. It is politically divided into two parts, Turkish Cypriots living in the Northern and Greek Cypriots living in the Southern part. Being a member of the European Union (EU), Southern Greek Cypriot Administration which has completed its integration is the country recognised by the world. On the other hand, Turkish Cypriot community, after foundation of Turkish Republic of Northern Cyprus (TRNC) in 1983, has been experiencing isolations, left alone by the EU, whereas most of its citizens are individually citizens of the EU. Having EU citizenships individually does not help for solving the problems of whole community. Due to non-recognition of the companies running marine activities in the TRNC, one of the main difficulties the country faces is lack of direct trade. It is not possible for ship owners to invest in their companies as they are overwhelmed by the economic conditions. As a result of that, EU funds cannot be used and the government does not provide any incentives for the marine activities and companies hardly take a step towards better future. There are 28 municipalities in TRNC. Although all areas in the country are within the borders of a municipality, there are six municipalities which can provide all services needed. Other municipalities are not able to provide all the services because they are small scaled. The central government takes the stage in this case and provides the services which the municipalities cannot do. However, this practice contravenes with the legitimacy concept.

Especially in coastal areas, local administrations have a lot of responsibilities. Coastlines are generally preferred for residential purposes, as people buy their second houses for vacation near coastal areas. This makes those regions attractive. Acceleration of industrialisation leads new requirements, so that the natural and ecological balance in coastal areas are corrupted. A system will be set up in consultation with stakeholders, e.g. the local administrations in the coastal areas, the government, nongovernmental organisations, universities, to determine long term objectives and take decisions to maintain the ecological balance, which may reduce the public concerns.

These objectives should be opened to the public consultation by taking legal actions (regulation, ordinance, legal decisions, and legislation) and preparing Energy Information Administration (EIA) Reports and planning procedures. The cooperation between the stakeholders led to coastal area management and integrated coastline management preventing the environmental issues in the countries having Mediterranean coasts. A system which will bring legitimacy principle to forefront should be foreseen. Any marine activity that local administrations have authority does not exist in the country yet despite all the efforts in order to activate the maritime transportation in various ways in the EU countries and Turkey.

\section{Marine Activities and Municipalities in TRNC}

Total coastline length of Cyprus Island is $782.5 \mathrm{~km}$, while the Northern part is 396 $\mathrm{km}(50.61 \%)$, the Southern part is 307.9 $\mathrm{km}(39.31 \%)$ and British bases area is 78.9 $\mathrm{km}(10.08 \%)$. As it is understood, $67 \%$ of TRNC consists of coastline which is 396 $\mathrm{km}$ long. Characteristics of shorelines in the Mediterranean Sea differ from country to country. Shorelines are continuously in change. In the Northern Cyprus coastline, there is a sensitively balanced habitat of various living creatures. 


\subsection{Harbour Works}

Gazimağusa (Famagusta) harbour has been a busy harbour, for transit cargo facilities, in history due to its location. Container transportation has become a promising activity for future. In case of a change in TRNC's political status, these activities would lead a significant return in the economy. For an increase in transit cargo capacity, good infrastructural projects and investment are required. All harbours in the country should be improved in technical and administrative way in order to be able to compete with the harbours in the southern Cyprus.

Cruise tourism is not developed in the country and the biggest factor is that it does not exist in the international arena. For the future, it is necessary to prepare infrastructure in the field of tourism at harbours. If good infrastructural steps are taken, the significant income will be ensured from cruising, especially through Gazimağusa harbour.

Yacht tourism at harbours and yacht accommodation capacity in the country are currently low. However, developing yacht tourism may pose advantages, in the future, due to island's location. It might increase the interest to the region by organising more activities. The biggest yacht tourism investment in TRNC is made in Karpaz peninsula (Karpazgate Marina, 300 yacht capacity) and the capacity is quite good. However, other tourism activities should being parallel with the activities organised at Marina.

\subsection{Maritime Affairs}

Maritime transportation is performed by 20 small and large companies. The harbours are in Gazimağusa (city harbour for cargo ships, Kalecik harbour for fuel, plaster, and cement), Kyrenia (yacht harbour and Teknecik filling facility) and Gemikonağı. Even if it is a small-scaled activity, container and Ro-Ro transportation are carried out in Kyrenia and Famagusta harbours. Besides, there are 6 fishing ports in the country. Fishing activities have very small contribution to the economy since fish stock at coasts is very low apart from Karpaz peninsula as well as not having deep sea fishing. As a result of this, the improvement of fishing is prevented. Nowadays, the amount of fish production is approximately 500 tonnes/year [1].

\subsection{Local administrations in the TRNC}

All residential areas in the country fall within the borders of municipalities which are 28 in total. Municipalities are the institutions which know the regional problems better than any other authority, as they are the closest governmental unit to the public. Ensuring the participation of public in the administration, improving life quality within borders of the municipality, regional public welfare, peace and safety, meeting the local requirements in a modernised attitude are among the main duties of the municipalities.

Local administrations should also have authority in the places such as harbours, fishing ports, marinas including coastal areas falling in their region. Municipalities should also ensure coordination with the NGOs (Non-Governmental Organisation), other public and private institutions, and try to minimise pressure from the other parties. Environmental problems are gradually increasing due to population increase especially in Kyrenia, irregular urbanization, consumption, frenzy and negligent people. The central government holds the authority of harbours and shorelines. Lack of coordination between the government and local administrations leads confusion in practice. Committees that have representatives from local governorates, NGOs and the central governments should be established under local administrations. Municipalities should work in compliance with the central government in respect of 
planning, implementing, controlling, taking measures and establishing appropriate policies according to current conditions. As a result, municipalities should be competent and effective at marinas, harbours, yacht harbours and shorelines. A Vessel Traffic Services (VTS) will be useful for this aim [2].

\subsection{Environmental Management} System and Current Status of Local Administrations

Just like improvements at the practices followed in environment policies and protection of natural habitats, there are some experiences in the improvement of the management systems. In the way of EU harmonisation, the most important model is ISO 14001. In Turkey where it is mandatory, many companies have been entitled to receive this certificate, whereas in TRNC it can be taken on voluntary basis. So, the standards function on voluntary principle. ISO 14001 Standard is based on "Plan-Implement-Control-Take Measure" methodology. Companies' objective for issuing this certificate is to prove their sensitivity to its customers and gain trust [3]. As the EU legislation is not in force in TRNC, current situation about these standards are not even getting closer to the desired level. The most important factor is that the central governments are reluctant to the compliance. The responsibilities and obligations of the municipalities can be defined as legal, technical, administrative, institutive, economical and human-related issues.

\section{Significance of Marine Habitat and Protection of Coastal Areas}

Environmental management is regulated under the Environment Law and the Constitution in the TRNC. Every citizen has right to live in a safe and balanced environment. Any natural or legal person shall not dispose, for any purpose, liquid, gas, or solid waste to the dams, streams or lakes, which potentially threatens public health or marine habitats. Improving, protecting environment and preventing pollution are the vital duties of the Government and natural/legal persons living in the country [4].

\subsection{Environmental Management}

It consists of implementing policies and strategies which are laid out in local, regional, national and global level for meeting current and future generations' needs without causing any impact on the environment, by using administrative, technical, legal, political, economic, sociological and cultural means in order to ensure sustainable use and improvement of natural and artificial environment aspects. Generally, environmental management aims to protect the nature both in short and long term, prevent deterioration, inspect disposal of waste, maintain good natural cycle, improve natural habitats [5]. Environmental management process covers establishment of an organisation which will ensure communication, planning, coordination and inspection both in public and private sector for protection, assessment and improvement of natural resources to give opportunity to living creatures to live in a safe and balanced environment [6]. As it can be understood from the definition, objective of the environmental management is to find an answer to the question of how and in what extent using of natural resources such as air, water and soil, preserve the ecological balance. Environmental management which prioritise presence of balance in use of natural resources may also be linked to sustainable development [7]. In the world, where the natural resources stay the same and population increases, the need of an environmental management is obvious [8]. Coastlines are generally preferred for residential purposes, as people buy their 
second houses for vacation near coastal areas. Privatisation of natural resources should be prevented, and those should be kept under authority of municipalities and the government. Environmental permits should not be given to the projects which have potential impact on the environment. City Planning permits for coastal areas should not be issued. Public consultation and involving NGOs to evaluations of any project are vital. In addition to global environmental problems, local and regional environmental problems also lower life quality. This presents the need for evaluating and solving the problems by handling them locally and considering them globally. Besides the importance of coordination among the countries to find solutions to global environmental issues, regional and local studies also play an important role. Pollution is mainly caused by human activities which lead deterioration and the environment can neither renew nor recycle itself. The most significant type of pollution is "air pollution", followed by "water pollution". Authorities try to minimise pollution by making studies at legal level. Another environmental problem is soil pollution due to the use of soil for wrong purposes and erosion. Lastly, noise problem for which some preventive measures are taken to minimise.

Measures and projects for environmental protection remain incapable since the pollution is continuously increasing and changing itself. For this reason, more extensive economical, technological, scientific, legal, social and political projects should be prepared in coordination other countries besides making legal amendments locally. The National Physical Plan (NPP) has been presented to all NGOs in the country for consultation. In strategical objective, natural resources, biological diversity, preserving historical and cultural heritage, preventing pollution and environmental risks are identified. In the plan, apart from the economic importance of the environment, policies would be written down for good management of ecological values, establishing tourist attractions, maintaining public health and high quality living standards. Protection of natural resources, biological diversity, historical and cultural heritage, elimination of pollution risk from the coastal areas and minimising the impact on the environment are key objectives of the Plan. According to TRNC Strategic Plan, it is stated that for a safe island having ecosystems with high biological diversity, the ability to act should be acquired together with the other countries which have coasts in the Mediterranean Sea. The Barcelona Convention provides a frameworkfor setting environmental standards and objectives that are agreed to by all the Contracting Parties, as well as for sharing important information for management. Just like in the other Mediterranean Coastal Countries, natural and cultural values of coastal areas are under duress due to pollution and urbanization pressure. Marine and Coastal Protection Areas should be established and inspected by all stakeholders in order to ensure sustainability. All living creatures in the Mediterranean are threatened because of marine pollution, fisheries, industrial facilities, overuse of resources and other human activities.

\subsection{Ecosystems in the Mediterranean}

Recently, the sea has become an ideal disposal area for the wastes generated as a result of human activities. It seems that the wastes disappear instantly in the sea. Tragically, a complex combination of pollutants exists in the coastal waters [9]. Since territorial and marine habitat differ, special expertise is needed in examining marine pollution, varying from one country to another. Therefore, information exchange among the countries is also important. For instance, if any accident occurs in the 
Mediterranean Sea, it affects all coastal areas in the region, so all relevant countries should be informed to minimise the impact. Governments which are participants of local or world organisations may establish an environment for protection, research and sustainable use of marine organisms and ecosystems; however, they may also cause conditions which have potential harm to aforementioned aspects. Existence of big differences between the industrialised and developing countries is the most important political obstacle in front of solving environmental problems. Marine habitats are under a great risk due the conflict between the countries. Reflection of this can clearly be seen in the Mediterranean, as the northern coast are surrounded by industrialised countries of Europe (France, Spain, Italy, Croatia, Greece, etc.) while the southern coasts by the developing countries (Morocco, Algeria, Tunisia, Libya and Egypt) [10].

\subsection{Protection of Coastal Areas}

Coast can be described in general as the point where territory and water meet. Yet, there are various physical factors and natural processes that shape the concept of coast. These cause the coast to have a dynamic structure, changing constantly. Coast, which varies widely depending on meteorological events, may be defined as a border line where water of the sea, lake and stream contacts the territory [11]. Coasts have been the focus points of modernisation in the history because of unique natural resources, easy access to international market and gained sociological importance in terms of use and settlement purposes. The coastal areas where settlement, social and economic activities are intense encounter some problems. There is a need of systematic and sustainable coastal management for protection, improvement and sustainable use of natural and environmental resources. It also plays an important role in national economy of many countries [12]. In the economies depending on population, there is a need for coastal areas and resources related to those. Problems such as an increase in destruction of natural resources as a result of natural disasters (erosion, flood, and earthquake) and unbalanced overuse of territorial and water resources in the regions can be observed. Air pollution, general environment pollution, noise and various complexities are the other related problems. Being aware of the existing resources being limited, many studies have been initialised to find long term solutions to the problems, in which long term protection of vital elements and areas in the region are discussed. In the development of our coastal areas, for maintaining balance between long term and short term solutions and understanding objectives, it is needed to support the system with appropriate and latest engineering technologies and socioeconomical elements. In consequence, coastal areas should be improved and arranged well as soon as possible. Aiming to maintain balance and preserve the integrity between nature, environment and species, pollutants should be identified and try to eliminate or minimise them by using Geographical Information Systems (GIS). Protection of Coastal Areas under TRNC Constitution (Article 38), coasts at the possession of the state shall only be used for public interest. Facilities owned by the state, vital and for public interest shall only be established in the area falling within 100 $\mathrm{m}$ coastlines for the coastal areas out of municipality borders and shall be subjected to fee with intention of national security, public order, public interest, public health and protection of environment. Sanctions and penalties shall apply on ships and other vessels that cause pollution, infringing Article 19 of Environment Law which lays down restrictions and bans, in coastal areas, territorial waters and harbours 
under authority of Turkish Republic of Northern Cyprus. Sanctions shall be applied by Harbours Department if the pollution is within the borders of interior and exterior of harbours, and by Coast Guard Command if the pollution is in territorial waters out of harbour borders.

The objectives of defining coastal area management methods are as follows [13];

- Identifying mutual effects of coast use and institutions in a balanced and planned way.

- Establishing a decision mechanism and integrated policy which cover all stakeholders, in order to promote common and balanced use of natural resources.

- Focusing on common shares in coast management.

- Preparing a status evaluation, estimating the future developments and identifying institutions" performances, strength and weaknesses for projects. In other words, SWOT analysis.

- There is a complex combination of pollutants in the coastal waters. So that, encouraging implementation of Environment Information Systems which reflect changes with presence of pollutants.

- The central government should involve local administrations, environment organizations, NGOs in planning and decision taking processes. Exchanging information among the stakeholders via Environmental Impact Assessment (EIA).

\section{Environmental Impact Assessment Reports}

Environmental Impact Assessment (EIA) shall mean studies for determining significant and insignificant effects of a project on the environment, minimising or preventing the significant impacts by taking some measures, evaluating proposal technologies and alternatives while taking those measures, implementing and monitoring the projects. Summary information about EIA reports in Turkey, European countries and TRNC is explained in the following parts.

\subsection{Environmental Impact Assessment Report in Turkey}

In the Republic of Turkey, EIA is defined as follows, in Article 4 "Definitions" under Environmental Impact Assessment Regulation published on 17 July 2007. Environmental Impact Assessment shall mean studies for determining significant and insignificant effects of a project on the environment, minimising or preventing the significant impacts by taking some measures, evaluating proposal technologies and alternatives while taking those measures, implementing and monitoring the projects. Control measure' principle which is among the main principles and objectives of environmental policies foreseen to take immediate measures before acquiring scientific evidence in case of a project is estimated to have any significant impact on the environment. Environmental Impact Assessment is also a tool for preventing potential impact on the environment [14].

\subsection{Environmental Impact Assessment in the European Union Countries}

Environmental Impact Assessment was revealed in the USA in 1970s, and then has was adopted as a binding Regulation for the EU countries, under Environment Directive (85/337) in 1985. In Turkey, EIA implementation came into force in 1983, with Article 10 of Environment Law (2872). Europe Environment Agency (AEA) is a key institution who plays an important role in the EIA subject. AEA is in charge of providing safe and independent information about the environment. It is also an information resource for public, beside the experts who work on developing, implementing 
and evaluating policies. Along with the EU countries, Norway, Iceland, Liechtenstein and Switzerland, Turkey is also a member of AEA. The agreement on Participation of Republic of Turkey in European Environment Agency and European Information and Observation Network was signed in 2000. In the adoption process of the agreement, it entered into force by the Law numbered as 4794 on 23/1/2003 at the Parliament of Turkey.

\subsection{Environmental Impact Assessment in Turkish Republic of Northern Cyprus}

An EIA report in the TRNC is evaluated by the Environment Protection Department under Ministry of Tourism, Environment and Culture. Environmental Impact Assessment shall be carried out for all project proposals which have potential significant impact on the environment. Strategic Environmental Assessment shall be carried out for all plans and programmes which have potential significant impact on the environment, aiming to contribute for taking environmental aspects into consideration, by the relevant sector, and to protect the environment. Until preliminary scanning is completed for the projects which are subject to EIA, no permit, licence, approval or incentive shall be given to the investor. These rules shall apply for both public and private sector, including the government, local administrations and other public institutions. EIA reports are evaluated by Environmental Impact Assessment Commission established under Environment Protection Department.

\subsection{Issues in Coastal Areas}

Coastal areas have been always preferred due to rich natural resources, cultural and historical values, beside their unique beauty. In connection with the great interest, various issues revealed in these regions. It can be listed as deterioration caused by touristic investments, constructional activities in the regions having natural significance, marine pollution due to bottom sweep, bailing and fish farms, pollution due to ship dismantling facilities and shipyards, water movement preventive physical and chemical intervention, excessive, out-of-season and destructive hunting, any filling and digging activities, deterioration of natural beauty due to erosion and accumulations, and uncontrolled structuring and technical and social infrastructure deficiencies in the activities held in coastal areas etc.

Coasts are used for purposes of settling, trade, industry, resource, tourism, recreation, waste disposal, food, etc. However, characteristics of coastal regions have been deteriorating and treads for natural balance have been revealed. Biological, hydro biological, ecological, climatic and physiological features are affected. While the coastal areas are considered as economic development for the central and local administrations, generally the main aim is to obtain benefit in a short period of time. In consequence of such an approach, deterioration of the coastal areas in a short while is obvious [11]. In order to develop an efficient coastal management in Turkey, common approach in the administration should be established by giving responsibilities and duties to local institutions and organizations, universities, regional structures and non-governmental organisations. Sustainable coastal area management can only be achieved by active participation of local people and institutions. This process is considerably dynamic [15].

\subsection{Coastal Policy of the European Union}

The coastal areas which are under effect of environmental problems have become one of the issues that are being dealt in EU countries. The European Union has carried studies and researches for taking 
specific measures devoted to the coastal areas. Moreover, in the EU countries there are many aspects which are dealt together; natural and cultural inheritance tourism, pollution and maritime safety, fisheries, environment natural, agricultural and touristic places, energy and industry. On these subjects, the EU has achieved to maintain a common practice. It is also important to share information and recommendations between the countries, in order to reach good practice on protection of the coastal areas. The European Union has not recently carried out any legal activity specifically related to the protection of coastal areas [16]. However, there are some rules in other legislations, such as; environmental impact evaluation, accessing information on neighbourhood problems, quality of drinkable and tap water, potential risk factors for animal and public health, marine habitat, treatment of waste water, purification of pollution, pollution in streams and lakes, environmental protection, poultry animals, preservation of species habitats. Nowadays, the European Union is making amendments in the regulations related to coastal and marine areas [17].

\subsection{Integrated and Combined Coastal Areas Management}

Integrated coast management approach was introduced, in United Nations Environment and Development Conference held in Rio, Brazil in 1992, as a tool for development and sustainability of coasts. The only difference of integrated coastal management is its scope. Previously "coastal area management" was common; however, nowadays "coastal zone management" has become more common expression. So recently, integrated coastal management has been the most popular expression among the others. Issues related to the coastal areas are handled individually on coastal area management studies. Various problems are also raised due to presence of more than one competent entity depending on legal and administrative gaps, conflicts between the relevant authorities, different educational background of departments' personnel or lack of information exchange between the authorities. Marine and coastal areas should be taken under protection for two reasons. First, these areas are main elements for the continuation of living on earth. Secondly, these areas bear various opportunities in maintaining continuous and balanced development. In this approach, as it was stated in the United Nations Marine Law Agreement, countries with coasts have all rights and responsibilities for protection and sustainable use of these areas. Those countries shall establish an integrated approach towards conservation of coastal areas, in terms of regional, national and local administrative levels and take measures depending on the current and potential environmental issues. Until today, although measures related to protection of sea and coastal resources have been taken by states at national, regional or local levels, their efforts have not maintained fully continuous and consistent development yet. However, applied pressure and deformation of natural qualities are gradually increasing. So, countries with coasts should use this integrated approach which aims to ensure continuity of decision making and implementation, take advantage of natural resources at a balanced level and have a preventive system instead of reparative.

Governments which have coastal areas should take measures, with support of international organisations, for maintaining biological species and protection of marine habitats. Every country shall also ensure improvement on data sources regarding coastal areas and marine habitat, development of communal and economical indications, regular environmental evaluation, techniques for benefiting from natural resources and activities, exchange of 
information and data with other countries and access of NGOs to the relevant data. Study results would be more helpful and efficient if international cooperation were maintained, especially for the developing countries.

Countries should act together to identify combined coastal management principles and organise a global conference to share experiences. Regional, sub-regional or international organizations which have global qualifications should support efforts of countries with coastal areas, especially developing ones. Rio Conference may be considered as a critical point for a change in the United Nations (UN) studies. One of the documents examined in detail at the conference was Agenda 21, Section 17. In that document, it is clearly stated that sectoral approach for the coastal areas has not been helpful and sufficient for the management of interrelated elements in the field. So, the new proposal is to have combined management of coastal areas and marine habitats. Yet, it is now clear that the sectoral approach is not sufficient and efficient for complex coastal area management system. In other words, there is a direct connection between the economic benefits and protection of natural habitats. For this reason, the coastal areas should be handled together with its all components, and also policies should be identified accordingly. Solution proposals focusing on sectors can also solve problems temporarily. It is vital to have a wider approach, including environmental, communal and economic factors. Combined management of coastal areas can be considered as an approach which would create solution opportunity for continuous and stable development.

\section{Local Administrations and Maritime Transportation}

Local administrations in TRNC have restricted activities to maritime transportation. The following part concludes the general situation and gives brief information about the maritime transportation in Turkey, EU and finally in TRNC.

\subsection{Maritime Transportation in Turkey and in the EU}

Most of the ships going around the shores were owned by foreigners during the Ottoman Period. So, shipping trade was run by the foreign ship owners. As the foreigners were holding stream vessels and carrying out trade activities, the Ottomans were trapped in period of regression. Decline of the Ottoman Empire speeded up during that period. Nevertheless, Aegean Sea was a popular destination for the ships. Europeans made co-investments and continued to be an arbiter in shipping trade, as a result of developments in industry. This big development in trade caused them to look for a country to market their products and created a sector in search of cheap food supply. Most significant development in the period of regression for the Ottomans was warships in Europe. While the Ottomans were busy modernising galleon ships, Europeans opened the era of stream vessels. Those vessels contributed to the development of trade and facilitated transportation to far harbours. They dominated the maritime transportation until the end of the Ottoman period. The developments in the Europe had not strengthened Ottomans, but only improved the harbours where trade activities were carried out.

By "Law on Coastwise Shipping and Perform Trade at Harbours and Maritime Territory" numbered as 815 in 19 April 1926, right of cabotage was given to Turkish citizens and the ships carrying Turkish flag. Treaty of Lausanne Trade Agreement introduced equality for foreign and Turkish ships, and also gave right of cabotage journey, fishing and harbour services to contracting parties carrying 
their national flags. Law on Cabotage was adopted by performing that right. Use of harbour services, carrying passengers, and towing, pilotage (guidance) along Turkish shoreline and between Turkish harbours could only be carried out by the ships holding Turkish flags. Law on Cabotage was adopted on 1 July 1926 and the date announced as Cabotage Holiday.

After the foundation of the Turkish Republic, economic growth in Istanbul and Izmir revealed the need of steamboats as the small boats could not meet the needs of public transportation. Public transportation in Istanbul was controlled by the municipality by a specific law. There were very few people working in maritime transportation sector. Since it was post-war period, naval shipyards took steps forward and had massive shipyards having capacity of constructing warships and submarines. In 1945's, private sector was holding steam vessels that were far from technology. Although the country was surrounded by the sea from three sides, Turkey missed many good opportunities due to lack of qualified personnel and insufficient capacity of private sector. Harbour and Maritime Affairs Department, City lines enterprises, State Railways and Harbours Administration Department were established under the Ministry of Public Affairs. Growth in the private sector during 1945 caused an increase in the capacity of the harbours, and in the modernisation of maritime sector in general. Capacity of these investments has been increasing until today [18]. However, giving authorities to municipalities on maritime transportation or inspection during Republic period was not found appropriate since they did not have technical capacity. The central government was trying to hold all the authorities among it. After 1970s, some duties and authorities started to be given to the local administrations due to developments in industry and technology. In 2004, Law on
Municipality Authorities numbered as 3723 was adopted, and maritime transportation duties and responsibilities were given to the municipalities. At the same time, the municipalities have the right to rent public transportation tools or hire service from other institutions [19]. Municipality Transportation Coordination Centres were established. However, Law on Maritime Undersecretariat was adopted, aiming to enable Undersecretariat to issue permits for maritime transportation so they had technical assessment authorities. Herein, the central government found a way to take authorities back by establishing such an Undersecretariat and made municipalities passive. Moreover, city lines were handed over to a company established under Istanbul Municipality. Ownership of docks was given to municipalities.

The government held management of maritime activities as a monopoly and it caused system to function slowly and many institutions were harmed due to political pressure. Privatisation showed rapid increase in Turkey during 1980s. Privatisation can be interpreted as handing over production tools partially or completely to the private sector. Especially, harbours and docks, marinas and all service sectors in maritime activities have been shared with the private sector.

Privatisation of harbours aims to create motivation by political objectives in order to decrease financial and administrative load in the long term while increasing economic gains from the developed and improved system [20]. In Turkey, privatised harbours have taken good steps, investments increased and container transportation has become at a good level. Especially in recent years, Turkey has showed an acceleration in maritime sector and found solution as a result of effective discussion. Procedures, recommendations and regulations have been prepared and adopted, with consultation to relevant 
institutions in maritime sector. Important steps are taken on organisational issues for more efficient future and a developed sector. Organisational structure of Ministry of Public Affairs has been changed and became Ministry of Public Affairs, Maritime and Communication. Harbour services have become very important in Turkey in recent years. Increasing number of harbours and quality in service helped harbours to be preferred for maritime transportation purposes [21].

Depending on the conditions varying in the EU countries, privatisation and derogation methods have been tried at the harbours. Few infrastructure services are still under the authority of public administration; harbour management is financed by the central government. Most of the maritime transportation activities have been handed over to the public sector in the EU. Exceptionally, harbours in the United Kingdom have been privatised with a special status. In other countries, local administrations do not prefer to run maritime transportation activities and hire harbours on long-term contracts, in other words they prefer privatisation. In the EU countries, $42 \%$ of foreign trade is carried out by sea. As most of the harbours in the world are in the Western Europe, the EU considers harbours strategically and economically

\subsection{Maritime Transportation in the TRNC}

Maritime transportation activities in the country are performed at two harbours, via ships carrying both TRNC flag and other foreign flags. Transportation affairs are held with various passenger, cargo and container ships that are registered in the country. Trade activities at Girne (Kyrenia) Tourism Harbour are not laid on the local administrations. On the other hand, passenger and cargo transportation are held in Gazimağusa Harbour. While cargo activities are carried out by the ships bearing various flags, there is only one ferry used for passenger transportation and this ferry is managed by Cyprus Maritime Transportation Enterprises; in which $51 \%$ share is under public authority. It is obviously understood that TRNC local administrations do not perform any activity in maritime transportation field.

\section{Results and Discussion}

This study revealed an analysis for better understanding of marine activities, municipalities, importance of marine environment and protection of coastal areas, local administrations and maritime transportation in the TRNC, by comparing it with other countries. It is foreseen that all the harbours in the country should be improved administratively and technically in order to be able to compete with the harbours in South. Cruising has a promising future in case of a political solution; however, the activities today are not sufficient due to countries' condition. Yachting is open to improvement and should be planned and run in parallel to other tourism activities. Fishing sector which creates added value is not foreseen to have an increase due to lack of far distant fishing activities. In other words, it is carried out unprofessionally. In other maritime transportation activities, individual entrepreneurship became prominent; however, it is far from the governments' support and tries to survive, since there are many worn ships that have flag problems. The main problem is that conditions are not improved in the country and it seems that there still needs to be time for a remarkable solution. Ensuring the participation of public in the administration, improving life quality within borders of the municipality, regional public wealth, peace and welfare, meeting the local requirements in a modernised attitude are among the main duties of the municipalities. The central government 
should be in cooperation with the municipalities for better implementation of legislation and regulations. Especially small scaled municipalities are in need of financial support by the central government and this decreases the quality of services they provide. Administrative and technical capacity in all municipalities should be increased. In order to succeed in environmental management, local administrations should be involved in the management activities

Law on Environment, ordinances and regulations issued under the law has ensured protection of coastal areas in the country because every citizen has right to live in safe and balanced environment. Short and long term actions should be taken for preserving environmental quality and preventing deterioration. Preparation of the national physical plan and emergency actions plans are a must. Similar to the other countries in the Mediterranean Sea, historical and cultural values of the country are threatened by the pollution and urbanisation pressure. Logically, all resources should be used for ensuring good conditions. There is a need of sustainable coastal management to identify future needs by protecting natural and environmental resources at coastal areas. Regarding the preparation and evaluation of Environmental Impact Assessment reports, all stakeholders and NGOs should be involved in order to reduce number of political decisions. A constant pressure on the coastal areas put sustainability in a difficult position. Policies should be drawn up in cooperation with the EU countries. All countries should apply integrated coastal area management in order to establish coordination when implementing decisions for better protection. Organisational structure, legal framework, communal rules, preserving national resources, compliance and most importantly ensuring participation are needed. However, collaborating with other countries would not be so easy due to political conditions of TRNC, although it is a unique island in the middle of the Mediterranean. An effective harmonisation process is strongly needed to carry out organisational tasks with the stakeholders. Regarding local administrations and maritime transportation, there is a slight improvement after the adoption of Cabotage Law in Turkey; however, after 1945 municipalities handed over harbours, marinas and maritime services to the private sector. Privatization has lead an increase in shipping trade and also caused a parallel increase in number of harbours and quality of services. In the TRNC, there is no local administration which provides maritime transportation services, whereas the public has approximately $51 \%$ shares of one enterprise that has one passenger ship.

\section{Conclusions}

In developed countries, there is a constant improvement in the technology. In TRNC, rapidly increasing population, pollution caused by inconvenient structures in coastal areas, prioritising individual interests instead of communal, methods used by the local administrations for solving environmental problems, lack of organising and insufficiency of personnel, and unfavourable conditions in improving environment policies and environmental planning have been causing the deterioration of the environment. Local administrations' responsibilities cannot be underestimated in the framework of problems. Although there have been some improvements in complying standards, the current condition is not satisfactory. On the other hand, although the local administrations have been given some responsibilities in TRNC, it is obvious that there are still some deficiencies. If the problems wanted to be solved from the source, local administrations should set 
up integrated coastal area management systems and environmental policies. So, sustainability of desired environmental management would reach a satisfactory level for the legitimacy in the country, but time is needed.

Even if the TRNC would be recognised internationally, following agreements and setting up strategies accordingly would be the first step. In this context, EU harmonisation studies should show progress. It is very essential to agree on authority sharing by discussing legislations, rules and regulations with the relevant stakeholders and to establish cooperation protocol between institutions and enterprises. National physical plan should enter into force as soon as possible and followed by long term plans and programmes, comparing socio-economical, ecological and cultural differences between the regions. Sustainable objectives should be identified in consultation with relevant institutions. Decentralisation may facilitate to determine the source of the problems and find quick solutions. While implementing incentives regarding development of shorelines, the whole coastal area should not be affected. In order to implement a safe project on the shoreline, maintain ecological balance, preserve natural and cultural heritage, gaps in the legislations should be filled and the authority conflict should be solved. Plans for sustainable progress may be drawn up in coordination, especially with the NGOs. First of all, an emergency plan would be drawn up and distribution of tasks among the relevant institutions would be decided in case of an environmental disaster. TRNC will be obliged to implement necessary rules in the near future, as the harmonisation to the EU legislation studies continue.

Due to the political reasons and power conflicts between local administrations and central government; decentralization, financial autonomy, enhancement of administrative autonomy, improvement of

Table 1: Principles Identified for Local Administrations

\begin{tabular}{|l|l|}
\hline \multicolumn{1}{|c|}{ Items } & \multicolumn{1}{c|}{ Solution Proposals } \\
\hline 1- Policy for Local Administrations & $\begin{array}{l}\text { Arrangements for the Improvement of Administrative Capacity, } \\
\text { Provision of Efficiency and Enhancement of Qualified Labour Force, } \\
\text { Development of the Effectiveness of the Institutional Capacity and } \\
\text { Institutionalism for Local Administrations }\end{array}$ \\
\hline $\begin{array}{l}\text { 2-Capacity Building and Service } \\
\text { Provision Methods in Local }\end{array}$ & $\begin{array}{l}\text { To ensure effectiveness in local services, establishment of quality and } \\
\text { quantity balance on quality basis, } \\
\text { Technical assistance to local administrations }\end{array}$ \\
\hline $\begin{array}{l}\text { 3-Democracy, Representation, } \\
\text { Larticipation and Transparency in }\end{array}$ & $\begin{array}{l}\text { To ensure effective participation of citizens in administration, } \\
\text { Enhancement of Democratic Representation of Local Administration } \\
\text { Organs and Improvement of Democracy Awareness }\end{array}$ \\
\hline $\begin{array}{l}\text { 4- Relations between Central } \\
\text { Administration and Local }\end{array}$ & $\begin{array}{l}\text { Review of duties, powers, responsibilities and relationship forms, } \\
\text { Main principles as democratization, rule of law and public interest. } \\
\text { Protection of public interest and benefit of society during decision- } \\
\text { making process in local administrations. }\end{array}$ \\
\hline 5-Inspection and Accountability & $\begin{array}{l}\text { Effectiveness of internal audit, To establish discretionary inspection } \\
\text { mechanisms. }\end{array}$ \\
\hline 6-Environment Management in & $\begin{array}{l}\text { Dissemination of "Local Environment Action Plan" practices and } \\
\text { Effective Implementation and Inspection of Environmental Impact } \\
\text { Assessment process, } \\
\text { Performance of Legal and Institutional Restructuring for Drafting Local } \\
\text { Environment Action Plans }\end{array}$ \\
\hline
\end{tabular}


income generation capacity, strengthening of institutionalisation in administration, public interest targeted service provision, improvement of political and local efforts on internal and external dynamics for development and growth should be ensured among the local administrations in TRNC Since the capacity of maritime sector is small in terms of developed policies and solution proposals, the peace process should reach an accomplishment in TRNC as soon as possible so that all sectors (public-private) can grow accordingly. The management of environment and coasts should be considered together.

This study is limited to the local administrations in TRNC, and it is aimed to make wide perspective by comparing rules and procedures in Turkey and in EU for better understanding of them. Furthermore, it is assessed the role of local administration in TRNC on the maritime activities and obtained a synthesis by using similar researches and operations not only in Turkey butalso in EU countries. As a result of that, it may be suggested that to determine a specific local administration in TRNC and to define the best local administration in EU and to make a benchmarking based on the maritime transportation systems for the further studies considering to marine environment pollution and also protection of coastal areas. In addition, another issue may be how local administrations are more effective in the maritime activities (such as collecting waste due to marine pollution, measures to decrease coastal and marine environment pollutions), and what the standards and legal aspects of that are.

\section{References}

[1] Debeş, M.E., Beyoğlu, A. and Kum, S., 2014, Fishing Activities in Turkish Republic of Northern Cyprus, Marine Science and Technology Bulletin, Vol. 3(2), pp. 15-19.
[2] Kum, S. and Debeş, M.E. (2016). Turkish Republic of Northern Cyprus Vessel Traffic Services (TRNC-VTS), Journal of ETA Maritime Science (JEMS), Vol. 4(2), pp. 175-187.

[3] ISO (2015). ISO 14001. Retrieved August 30, 2015 from http://www. standartkalite.com/iso 14001_nedir. htm.

[4] KKTC Mahkemeleri (2015). Kuzey Kıbrıs Türk Cumhuriyeti Çevre Yasası. Retrieved October 18, 2015 from http://www.mahkemeler.net/cgibin/default.aspx

[5] Kızılboğa, R. and Batal, S. (2012). The roles and importance of local governments in the solution of environmental problems in Turkey. Mustafa Kemal University Journal of Social Sciences Institute, 9 (20), 191-212. Retrieved May 10, 2015 from http://sbed.mku.edu.tr/article/ viewFile/1038000353/1038000184.

[6] Keleş, R., Hamamcı, C. and Çoban, A. (2009). Çevre Politikası. Ankara: İmge Kitapevi.

[7] Yılmaz, A., Bozkurt, Y. ve Taşkın, E. (2005). Doğal kaynakların korunmasında çevre yönetiminin etkinliği. DPÜ Sosyal Bilimler Enstitüsü Dergisi, 13, 15-30.

[8] Geray, C. (1998). Yerel yönetimler ve çevre. Çağdaş yerel yönetimler dergisi, 7(3), 57-64.

[9] Ornat, A.L. (2006). Akdenizde Deniz ve Kıyı Koruma Alanları'nın Oluşturulması ve Yönetilmesi için Rehber. Retrieved April 17, 2015 from http://dcm.dka.gov. tr /App_Upload/1.AKDENIZ_DKA_ OLUSTURULMASI_VE_YONETILMESI_ ICIN_REHBER.pdf.

[10] Badalamenti, F., Ramos, A.A., Voultsiadou, E., Sánchez Lizaso, J.L., D’anna, G., Pipitone, C., Mas, J., Ruiz Fernandez, J.A., Whitmarsh, D., Riggio, S. (2000). Cultural and socio-economic 
impacts of Mediterranean marine protected areas. Environmental Conservation, 27(2), 110-125.

[11] Kibaroğlu, D., Şişman, A. ve Sesli F.A. (2009). Kıyı Bilgi Sisteminde Veriler ve Veri Kaynakları. TMMOB Harita ve Kadastro Mühendisleri Odası, Coğrafi Bilgi Sistemleri Kongresi, İzmir: Tepekule Kongre ve Sergi Merkezi.

[12] Kay, R. and Alder, J. (2005). Coastal Planning and Management, 2nd Ed.. CRC Press, ISBN-10: 0415317738.

[13] Sesli, F. A., Aydınoğlu, A. C.. ve Akyol, N. (2003). Kıyı Alanlarının Yönetimi. Türk Mühendis ve Mimar Odaları Birliği Harita ve Kadastro Mühendisleri Odası 9. Türkiye Harita Bilimsel ve Teknik Kurultayl, 757-768, Ankara.

[14] Güler, C.. ve Çobanoğlu, Z. (1994). Çevresel Etki Değerlendirmesi. Çevre Sağlığı Temel Kaynak Dizisi No: 36, Ankara: TC Sağlık Bakanlığı. Retrieved March 3, 2015 from http://sbu.saglik. gov.tr/Ekutuphane/kitaplar/css36. pdf.

[15] Akyarll, A. (2002). Türkiye kiyı mühendisliği araştırmaları. Kıyı ve Liman Mühendisliği. Türkiye Mühendislik Haberleri (TMH) Sayı 420-422/4-6, 69-70. Retrieved September 16, 2014 from www. imo.org.tr/resimler/dosya ekler/13fbecf46fabf2f_ek.pdf?dergi.

[16] DG Environment, Nuclear Safety and Civil Protection (1996). Demonstration Programme on Integrated Management of Coastal Zones, 3, Information Document European Commission Services.

[17] Gibson, J. (1999). Legal and Regulatory Bodies: Appropriateness to Integrated Coastal Zone Management: Final Report. European Commission - DG XI.D.2, 50-60, Macalister Elliott and Partners Ltd., Hampshire.
[18] Özturk, A.İ. (2010). Osmanlı'dan Cumhuriyet'e İmtiyaz Usuluyle Yürütülen İstanbul Belediye Hizmetleri (Yap - İşlet - Devret Uygulaması / 1852-1964). İstanbul: Kültür.

[19] Official Gazette (2005). Büyükșehir Belediyesi Kanunu, Sayı: 25531. Retrieved February 20, 2015 from http://www.resmigazete.gov.tr/ eskiler/2004/07/ 20040723.htm.

[20] Frankel, E.G. (1992). Hierarchical logic in shipping policy and decision making. Maritime Policy and Management, 19 (3), 211-221. http:// dx.doi.org/10.1080/751248662.

[21] Turkey Maritime Enterprises (2014). 2014 Sector Report. Retrieved June 12, 2015 from http://www.tdi.gov. tr/kurulusumuzun-2014-yili-yillikfaaliyet-raporu-2/. 